4

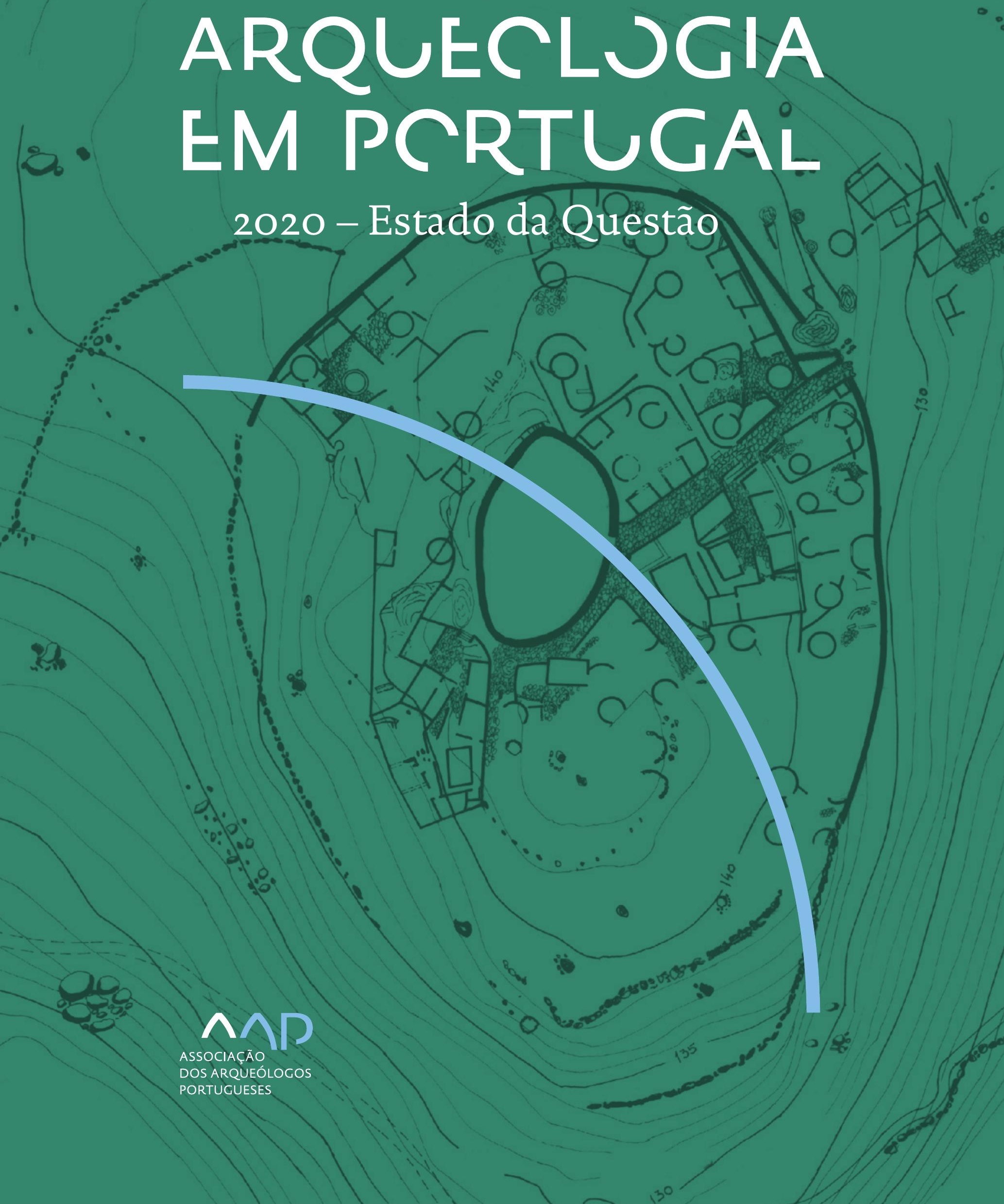


Coordenação editorial: José Morais Arnaud, César Neves e Andrea Martins Design gráfico: Flatland Design

AAP - ISBN: 978-972-9451-89-8

CITCEM - ISBN: 978-989-8970-25-1

Associação dos Arqueólogos Portugueses e CITCEM

Lisboa, 2020

O conteúdo dos artigos é da inteira responsabilidade dos autores. Sendo assim a Associação dos Arqueólogos Portugueses declina qualquer responsabilidade por eventuais equívocos ou questões de ordem ética e legal.

Desenho de capa:

Planta do castro de Monte Mozinho (Museu Municipal de Penafiel).

\section{$\hat{\wedge} \mathrm{P}$}

DOS ARQUEÓLOGOS PORTUGUESES

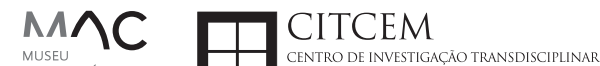
MUSEU
ARQUELLÓGICO
DO CARMO
U.PORTO

FLUP FACULDADE DE LETRAS
UNIVERSIDADE DO PORTO

Apoio

EC para a Ciência 


\section{Índice}

15 Prefácio

José Morais Arnaud

\section{Historiografia e Teoria}

17 Território, comunidade, memória e emoção: a contribuição da história da arqueologia (algumas primeiras e breves reflexões)

Ana Cristina Martins

25 Como descolonizar a arqueologia portuguesa?

Rui Gomes Coelho

41 Arqueologia e Modernidade: uma revisitação pessoal e breve de alguns aspetos da obra homónima de Julian Thomas de 2004

Vítor Oliveira Jorge

57 Dados para a História das Mulheres na Arqueologia portuguesa, dos finais do século XIX aos inícios do século XX: números, nomes e tabelas

Filipa Dimas / Mariana Diniz

73 Retractos da arqueologia portuguesa na imprensa: (in)visibilidades no feminino

Catarina Costeira / Elsa Luís

85 Arqueologia e Arqueólogos no Norte de Portugal Jacinta Bugalhão

101 Vieira Guimarães (1864-1939) e a arqueologia em Tomar: uma abordagem sobre o território e as gentes

João Amendoeira Peixoto / Ana Cristina Martins

115 Os memoráveis? A arqueologia algarvia na imprensa nacional e regional na presente centúria (2001-2019): características, visões do(s) passado(s) e a arqueologia

enquanto marca

Frederico Agosto / João Silva

129 A Evolução da Arqueologia Urbana e a Valorização Patrimonial no Barlavento Algarvio: Os casos de Portimão e Silves

Artur Mateus / Diogo Varandas / Rafael Boavida

\section{Gestão, Valorização e Salvaguarda do Património}

145 O Caderno Reivindicativo e as condições de trabalho em Arqueologia Miguel Rocha / Liliana Matias Carvalho / Regis Barbosa / Mauro Correia / Sara Simões / Jacinta Bugalhão / Sara Brito / Liliana Veríssimo Carvalho / Richard Peace / Pedro Peça / Cézer Santos

155 Os Estudos de Impacte Patrimonial como elemento para uma estratégia sustentável de minimização de impactes no âmbito de reconversões agrícolas Tiago do Pereiro

165 Salvaguarda de Património arqueológico em operações florestais: gestão e sensibilização Filipa Bragança / Gertrudes Zambujo / Sandra Lourenço / Belém Paiva / Carlos Banha / Frederico Tatá Regala / Helena Moura / Jacinta Bugalhão / João Marques / José Correia / Pedro Faria / Samuel Melro

179 Os valores do Património: uma investigação sobre os Sítios Pré-históricos de Arte Rupestre do Vale do Rio Côa e de Siega Verde José Paulo Francisco 
189 Conjugando recursos arqueológicos e naturais para potenciar as visitas ao Geoparque Litoral de Viana do Castelo (Noroeste de Portugal)

Hugo A. Sampaio / Ana M.S. Bettencourt / Susana Marinho / Ricardo Carvalhido

203 Áreas de Potencial Arqueológico na Região do Médio Tejo: Modelo Espacial Preditivo Rita Ferreira Anastácio / Ana Filipa Martins / Luiz Oosterbeek

223 Património Arqueológico e Gestão Territorial: O contributo da Arqueologia para a revisão do PDM de Avis

Ana Cristina Ribeiro

237 A coleção arqueológica do extinto Museu Municipal do Porto - Origens, Percursos e Estudos

Sónia Couto

251 Valpaços - uma nova carta arqueológica

Pedro Pereira / Maria de Fátima Casares Machado

263 Arqueologia na Cidade de Peniche

Adriano Constantino / Luís Rendeiro

273 Arqueologia Urbana: a cidade de Lagos como caso de Estudo Cátia Neto

285 Estratégias de promoção do património cultural subaquático nos Açores. O caso da ilha do Faial

José Luís Neto / José Bettencourt / Luís Borges / Pedro Parreira

297 Carta Arqueológica da Cidade Velha: Uma primeira abordagem

Jaylson Monteiro / Nireide Tavares / Sara da Veiga / Claudino Ramos / Edson Brito /

Carlos Carvalho / Francisco Moreira / Adalberto Tavares

311 Antropologia Virtual: novas metodologias para a análise morfológica e funcional Ricardo Miguel Godinho / Célia Gonçalves

\section{Didáctica da Arqueologia}

327 Como os projetos de Arqueologia podem contribuir para uma comunidade culturalmente mais consciente Alexandra Figueiredo / Claúdio Monteiro / Adolfo Silveira / Ricardo Lopes

337 Educação Patrimonial - Um cidadão esclarecido é um cidadão ativo! Ana Paula Almeida

351 A aproximação da Arqueologia à sala de aula: um caso de estudo no $3^{\circ}$ ciclo do Ensino Básico Luís Serrão Gil

363 Arqueologia 3.o - Pensar e comunicar a Arqueologia para um futuro sustentável Mónica Rolo

377 “Conversa de Arqueólogos" - Divulgar a Arqueologia em tempos de Pandemia Diogo Teixeira Dias

389 Escola Profissional de Arqueologia: desafios e oportunidades Susana Nunes / Dulcineia Pinto / Júlia Silva / Ana Mascarenhas

399 Os Museus de Arqueologia e os Jovens: a oferta educativa para o público adolescente Beatriz Correia Barata / Leonor Medeiros

411 O museu universitário como mediador entre a ciência e a sociedade: o exemplo da secção de arqueologia no Museu de História Natural e da Ciência da Universidade do Porto (MHNC-UP)

Rita Gaspar 
421 Museu de Lanifícios: Real Fábrica de Panos. Atividades no âmbito da Arqueologia Beatriz Correia Barata / Rita Salvado

427 Arqueologia Pública e o caso da localidade da Mata (Torres Novas) Cláudia Manso / Ana Rita Ferreira / Cristiana Ferreira / Vanessa Cardoso Antunes

431 Do sítio arqueológico ao museu: um percurso (também) didático Lídia Fernandes

447 Estão todos convidados para a Festa! E para dançar também... O projecto do Serviço Educativo do Museu Arqueológico do Carmo na $5^{\underline{a}}$ Edição da Festa da Arqueologia Rita Pires dos Santos

459 O “Clã de Carenque”, um projeto didático de arqueologia Eduardo Gonzalez Rocha

469 Mediação cultural: peixe que puxa carroça nas Ruínas Romanas de Troia Inês Vaz Pinto / Ana Patrícia Magalhães / Patrícia Brum / Filipa Santos

481 Didática Arqueológica, experiências do Projeto Mértola Vila Museu Maria de Fátima Palma / Clara Rodrigues / Susana Gómez / Lígia Rafael

\section{Arte Rupestre}

497 Os inventários de arte rupestre em Portugal Mila Simões de Abreu

513 O projeto FIRST-ART - conservação, documentação e gestão das primeiras manifestações de arte rupestre no Sudoeste da Península Ibérica: as grutas do Escoural e Maltravieso Sara Garcês / Hipólito Collado / José Julio García Arranz / Luiz Oosterbeek / António Carlos Silva / Pierluigi Rosina / Hugo Gomes / Anabela Borralheiro Pereira / George Nash / Esmeralda Gomes / Nelson Almeida / Carlos Carpetudo

523 Trabalhos de documentação de arte paleolítica realizados no âmbito do projeto PalæoCôa André Tomás Santos / António Fernando Barbosa / Luís Luís / Marcelo Silvestre / Thierry Aubry

537 Imagens fantasmagóricas, silhuetas elusivas: as figuras humanas na arte do Paleolítico Superior da região do Côa Mário Reis

$55^{1}$ Os motivos zoomórficos representados nas placas de tear de Vila Nova de São Pedro (Azambuja, Portugal) Andrea Martins / César Neves / José M. Arnaud / Mariana Diniz

571 Arte Rupestre do Monte de Góios (Lanhelas, Caminha). Síntese dos resultados dos trabalhos efectuados em 2007-2009 Mário Varela Gomes

599 Gravuras rupestres de barquiformes no Monte de S. Romão, Guimarães, Noroeste de Portugal Daniela Cardoso

613 Círculos segmentados gravados na Bacia do Rio Lima (Noroeste de Portugal): contributos para o seu estudo Diogo Marinho / Ana M.S. Bettencourt / Hugo Aluai Sampaio

631 Equídeos gravados no curso inferior do Rio Mouro, Monção (NW Portugal). Análise preliminar Coutinho, L.M. / Bettencourt, A.M.S / Sampaio, Hugo A.S

645 Paletas na Arte Rupestre do Noroeste de Portugal. Inventário preliminar Bruna Sousa Afonso / Ana M. S. Bettencourt / Hugo A. Sampaio 


\section{Pré-História}

661 O projeto Miño/Minho: balanço de quatro anos de trabalhos arqueológicos Sérgio Monteiro-Rodrigues / João Pedro Cunha-Ribeiro / Eduardo Méndez-Quintas / Carlos Ferreira / Pedro Xavier / José Meireles / Alberto Gomes / Manuel Santonja / Alfredo Pérez-González

677 A ocupação paleolítica da margem esquerda do Baixo Minho: a indústria lítica do sítio de Pedreiras 2 (Monção, Portugal) e a sua integração no contexto regional Carlos Ferreira / João Pedro Cunha-Ribeiro / Sérgio Monteiro-Rodrigues / Eduardo Méndez-Quintas / Pedro Xavier / José Meireles / Alberto Gomes / Manuel Santonja / Alfredo Pérez-González

693 O sítio acheulense do Plistocénico médio da Gruta da Aroeira Joan Daura / Montserrat Sanz / Filipa Rodrigues / Pedro Souto / João Zilhão

703 As sociedades neandertais no Barlavento algarvio: modelos preditivos com recurso aos SIG

Daniela Maio

715 A utilização de quartzo durante o Paleolítico Superior no território dos vales dos rios Vouga e Côa

Cristina Gameiro / Thierry Aubry / Bárbara Costa / Sérgio Gomes / Luís Luís / Carmen Manzano / André Tomás Santos

733 Uma perspetiva diacrónica da ocupação do concheiro do Cabeço da Amoreira (Muge, Portugal) a partir da tecnologia lítica Joana Belmiro / João Cascalheira / Célia Gonçalves

745 Novos dados sobre a Pré-história Antiga no concelho de Palmela. A intervenção arqueológica no sítio do Poceirão I

Michelle Teixeira Santos

757 Problemas em torno de Datas Absolutas Pré-Históricas no Norte do Alentejo Jorge de Oliveira

771 Povoamento pré-histórico nas áreas montanhosas do NO de Portugal: o Abrigo 1 de Vale de Cerdeira Pedro Xavier / José Meireles / Carlos Alves

783 Apreciação do povoamento do Neolítico Inicial na Baixa Bacia do Douro. A Lavra I (Serra da Aboboreira) como caso de estudo Maria de Jesus Sanches

797 O Processo de Neolitização na Plataforma do Mondego: os dados do Sector C do Outeiro dos Castelos de Beijós (Carregal do Sal)

João Carlos de Senna-Martinez / José Manuel Quintã Ventura / Andreia Carvalho / Cíntia Maurício

823 Novos trabalhos na Lapa da Bugalheira (Almonda, Torres Novas) Filipa Rodrigues / Pedro Souto / Artur Ferreira / Alexandre Varanda / Luís Gomes / Helena Gomes / João Zilhão

837 A pedra polida e afeiçoada do sítio do Neolítico médio da Moita do Ourives (Benavente, Portugal)

César Neves

857 Casal do Outeiro (Encarnação, Mafra): novos contributos para o conhecimento do povoamento do Neolítico final na Península de Lisboa.

Cátia Delicado / Carlos Maneira e Costa / Marta Miranda / Ana Catarina Sousa

873 Stresse infantil, morbilidade e mortalidade no sítio arqueológico do Neolítico Final/ Calcolítico ( $4^{\circ}$ e $3^{\circ}$ milénio a.C.) do Monte do Carrascal 2 (Ferreira do Alentejo, Beja) Liliana Matias de Carvalho / Sofia N. Wasterlain 
885 Come together: O Conjunto Megalítico das Motas (Monção, Viana do Castelo) e as expressões Campaniformes do Alto Minho Ana Catarina Basílio / Rui Ramos

899 Trabalhos arqueológicos no sítio Calcolítico da Pedreira do Poio Carla Magalhães / João Muralha / Mário Reis / António Batarda Fernandes

913 O sítio arqueológico de Castanheiro do Vento. Da arquitectura do sítio à arquitectura de um território João Muralha Cardoso

925 Estudo zooarqueológico das faunas do Calcolítico final de Vila Nova de São Pedro (Azambuja, Portugal): Campanhas de 2017 e 2018 Cleia Detry / Ana Catarina Francisco / Mariana Diniz / Andrea Martins / César Neves / José Morais Arnaud

943 As faunas depositadas no Museu Arqueológico do Carmo provenientes de Vila Nova de São Pedro (Azambuja): as campanhas de 1937 a 1967 Ana Catarina Francisco / Cleia Detry / César Neves / Andrea Martins / Mariana Diniz / José Morais Arnaud

959 Análise funcional de material lítico em sílex do castro de Vila Nova de S. Pedro (Azambuja, Portugal): uma primeira abordagem Rafael Lima

971 O recinto da Folha do Ouro 1 (Serpa) no contexto dos recintos de fossos calcolíticos alentejanos

António Carlos Valera / Tiago do Pereiro / Pedro Valério / António M. Monge Soares

\section{Proto-História}

987 Produção de sal marinho na Idade do Bronze do noroeste Português. Alguns dados para uma reflexão

Ana M. S. Bettencourt / Sara Luz / Nuno Oliveira / Pedro P. Simões / Maria Isabel C. Alves / Emílio Abad-Vidal

1001 A estátua-menir do Pedrão ou de São Bartolomeu do Mar (Esposende, noroeste de Portugal) no contexto arqueológico da fachada costeira de entre os rios Neiva e Cávado Ana M. S. Bettencourt / Manuel Santos-Estévez / Pedro Pimenta Simões / Luís Gonçalves

1015 O Castro do Muro (Vandoma/Baltar, Paredes) - notas para uma biografia de ocupação da Idade do Bronze à Idade Média

Maria Antónia D. Silva / Ana M. S. Bettencourt / António Manuel S. P. Silva / Natália Félix

1031 Do Bronze Final à Idade Média - continuidades e hiatos na ocupação de Povoados em Oliveira de Azeméis João Tiago Tavares / Adriaan de Man

1041 As faunas do final da Idade do Bronze no Sul de Portugal: leituras desde o Outeiro do Circo (Beja)

Nelson J. Almeida / Íris Dias / Cleia Detry / Eduardo Porfírio / Miguel Serra

1055 A Espada do Monte das Oliveiras (Serpa) - uma arma do Bronze Pleno do Sudoeste Rui M. G. Monge Soares / Pedro Valério / Mariana Nabais / António M. Monge Soares

1065 São Julião da Branca (Albergaria-a-Velha) - Investigação e valorização de um povoado do Bronze Final

António Manuel S. P. Silva / Paulo A. P. Lemos / Sara Almeida e Silva / Edite Martins de Sá

1083 Do castro de S. João ao Mosteiro de Santa Clara: notícia de uma intervenção arqueológica, em Vila do Conde Rui Pinheiro 
1095 O castro de Ovil (Espinho), um quarto de século de investigação - resultados e questões em aberto

Jorge Fernando Salvador / António Manuel S. P. Silva

1111 O Castro de Salreu (Estarreja), um povoado proto-histórico no litoral do Entre Douro e Vouga

Sara Almeida e Silva / António Manuel S. P. Silva / Paulo A. P. Lemos / Edite Martins de Sá

1127 Castro de Nossa Senhora das Necessidades (Sernancelhe): uma primeira análise artefactual Telma Susana O. Ribeiro

${ }_{1141}$ A cividade de Bagunte. O estado atual da investigação Pedro Brochado de Almeida

1153 Zoomorfos na cerâmica da Idade do Ferro no NW Peninsular: inventário, cronologias e significado Nuno Oliveira / Cristina Seoane

1163 Vasos gregos em Portugal: diferentes maneiras de contar a história do intercâmbio cultural na Idade do Ferro

Daniela Ferreira

1175 Os exotica da necrópole da Idade do Ferro do Olival do Senhor dos Mártires (Alcácer do Sal) no seu contexto regional

Francisco B. Gomes

\section{Antiguidade Clássica e Tardia}

1191 O uso de madeira como combustível no sítio da Quinta de Crestelos (Baixo Sabor): da Idade do Ferro à Romanização Filipe Vaz / João Tereso / Sérgio Simões Pereira / José Sastre / Javier Larrazabal Galarza / Susana Cosme / José António Pereira / Israel Espi

1207 Cultivos de Época Romana no Baixo Sabor: continuidade em tempos de mudança? João Pedro Tereso / Sérgio Simões Pereira / Filipe Santos / Luís Seabra / Filipe Vaz

1221 A casa romana na Hispânia: aplicação dos modelos itálicos nas províncias ibéricas Fernanda Magalhães / Diego Machado / Manuela Martins

1235 As pinturas murais romanas da Rua General Sousa Machado, n. ${ }^{5}$ 1, Chaves José Carvalho

1243 Trás do Castelo (Vale de Mir, Pegarinhos, Alijó) - Uma exploração agrícola romana do Douro

Tony Silvino / Pedro Pereira

1255 A sequência de ocupação no quadrante sudeste de Bracara Augusta: as transformações de uma unidade doméstica Lara Fernandes / Manuela Martins

1263 Os Mosaicos com decoração geométrica e geométrico-vegetalista dos sítios arqueológicos da área do Conuentus Bracaraugustanus. Novas abordagens quanto à conservação, restauro, decoração e datação Maria de Fátima Abraços / Licínia Wrench

1277 “Casa Romana” do Castro de São Domingos (Cristelos, Lousada): Escavação, Estudo e Musealização Paulo André de P. Lemos

1291 A arqueobotânica no Castro de Guifões (Matosinhos, Noroeste de Portugal): O primeiro estudo carpológico

Luís Seabra / Andreia Arezes / Catarina Magalhães / José Varela / João Pedro Tereso 
1305 Um Horreum Augustano na Foz do Douro (Monte do Castelo de Gaia, Vila Nova de Gaia) Rui Ramos

1311 Ponderais romanos na Lusitânia: padrões, formas, materiais e contextos de utilização Diego Barrios Rodríguez

1323 Um almofariz centro-itálico na foz do Mondego

Marco Penajoia

1335 Estruturas romanas de Carnide - Lisboa Luísa Batalha / Mário Monteiro / Guilherme Cardoso

1347 O contexto funerário do sector da "necrópole NO" da Rua das Portas de S. Antão (Lisboa): o espaço, os artefactos, os indivíduos e a sua interconectividade na interpretação do passado Sílvia Loja, José Carlos Quaresma, Nelson Cabaço, Marina Lourenço, Sílvia Casimiro, Rodrigo Banha da Silva, Francisca Alves-Cardoso

${ }_{1361}$ Povoamento em época Romana na Amadora - resultados de um projeto pluridisciplinar Gisela Encarnação / Vanessa Dias

1371 A Arquitectura Residencial em Mirobriga (Santiago do Cacém): contributo a partir de um estudo de caso Filipe Sousa / Catarina Felício

${ }_{1385}$ O fim do ciclo. Saneamento e gestão de resíduos nos edifícios termais de Mirobriga (Santiago do Cacém)

Catarina Felício / Filipe Sousa

1399 Balsa, Topografia e Urbanismo de uma Cidade Portuária Vítor Silva Dias / João Pedro Bernardes / Celso Candeias / Cristina Tété Garcia

1413 No Largo das Mouras Velhas em Faro (2017): novas evidências da necrópole norte de Ossonoba e da sua ocupação medieval Ricardo Costeira da Silva / Paulo Botelho / Fernando Santos / Liliana Nunes

1429 Instrumentos de pesca recuperados numa fábrica de salga em Ossonoba (Faro) Inês Rasteiro / Ricardo Costeira da Silva / Paulo Botelho

1439 A Necrópole Romana do Eirô, Duas Igrejas (Penafiel): intervenção arqueológica de 2016 Laura Sousa / Teresa Soeiro

1457 Ritual, descarte ou afetividade? A presença de Canis lupus familiaris na Necrópole Noroeste de Olisipo (Lisboa)

Beatriz Calapez Santos / Sofia Simões Pereira / Rodrigo Banha da Silva / Sílvia Casimiro / Cleia Detry / Francisca Alves Cardoso

1467 Dinâmicas económicas em Bracara na Antiguidade Tardia Diego Machado / Manuela Martins / Fernanda Magalhães / Natália Botica

1479 Cerâmicas e Vidros da Antiguidade Tardia do Edifício sob a Igreja do Bom Jesus (Vila Nova de Gaia) Joaquim Filipe Ramos

1493 Novos contributos para a topografia histórica de Mértola no período romano e na Antiguidade Tardia Virgílio Lopes

\section{8. Época Medieval}

1511 Cerâmicas islâmicas no Garb setentrional "português": algumas evidências e incógnitas Constança dos Santos / Helena Catarino / Susana Gómez / Maria José Gonçalves / Isabel Inácio / Gonçalo Lopes / Jacinta Bugalhão / Sandra Cavaco / Jaquelina Covaneiro / Isabel Cristina Fernandes / Ana Sofia Gomes 
1525 Contributo para o conhecimento da cosmética islâmica, em Silves, durante a Idade Média Rosa Varela Gomes

1537 Yábura e o seu território - uma análise histórico-arqueológica de Évora entre os séculos VIII-XII José Rui Santos

1547 A encosta sul do Castelo de Palmela - resultados preliminares da escavação arqueológica Luís Filipe Pereira / Michelle Teixeira Santos

1559 A igreja de São Lourenço (Mouraria, Lisboa): um conjunto de silos e de cerâmica medieval islâmica

Andreia Filipa Moreira Rodrigues

1571 O registo material de movimentações populacionais no Médio Tejo, durante os séculos XII-XIII. Dois casos de "sunken featured buildings", nos concelhos de Cartaxo e Torres Novas Marco Liberato / Helena Santos / Nuno Santos

1585 O nordeste transmontano nos alvores da Idade média. Notas para reflexão Ana Maria da Costa Oliveira

1601 Sepulturas escavadas na rocha do Norte de Portugal e do Vale do Douro: primeiros resultados do Projecto SER-NPVD

Mário Jorge Barroca / César Guedes / Andreia Arezes / Ana Maria Oliveira

1619 "Portucalem Castrum Novum" entre o Mediterrâneo e o Atlântico: o estudo dos materiais cerâmicos alto-medievais do arqueossítio da rua de D. Hugo, nํ. 5 (Porto) João Luís Veloso

1627 A Alta Idade Média na fronteira de Lafões: notas preliminares sobre a Arqueologia no Concelho de Vouzela

Manuel Luís Real / Catarina Tente

1641 Um conjunto cerâmico medieval fora de portas: um breve testemunho aveirense Susana Temudo

${ }_{1651}$ Os Lóios do Porto: uma perspetiva integrada no panorama funerário da Baixa Idade Média à Época Moderna em meios urbanos em Portugal

Ana Lema Seabra

1659 O Caminho Português Interior de Santiago como eixo viário na Idade Média Pedro Azevedo

1665 Morfologia Urbana: Um exercício em torno do Castelo de Ourém André Donas-Botto / Jaqueline Pereira

1677 Intervenção arqueológica na Rua Marquês de Pombal/Largo do Espírito Santo (Bucelas, Loures)

Florbela Estêvão / Nathalie Antunes-Ferreira / Dário Ramos Neves / Inês Lisboa

1691 O Cemitério Medieval do Poço do Borratém e a espacialidade funerária na cidade de Lisboa Inês Belém / Vanessa Filipe / Vasco Noronha Vieira / Sónia Ferro / Rodrigo Banha da Silva

1705 Um Espaço Funerário Conventual do séc. XV em Lisboa: o caso do Convento de São Domingos da Cidade Sérgio Pedroso / Sílvia Casimiro / Rodrigo Banha da Silva / Francisca Alves Cardoso

\section{9. Época Moderna e Contemporânea}

1721 Arqueologia Moderna em Portugal: algumas reflexões críticas em torno da quantificação de conjuntos cerâmicos e suas inferências históricas e antropológicas Rodrigo Banha da Silva / André Bargão / Sara da Cruz Ferreira

1733 Faianças de dois contextos entre os finais do século XVI e XVIII do Palácio dos Condes de Penafiel, Lisboa

Martim Lopes / Tomás Mesquita 
1747 Um perfil de consumo do século XVIII na foz do Tejo: O caso do Mercado da Ribeira, Lisboa Sara da Cruz Ferreira / Rodrigo Banha da Silva / André Bargão

1761 Os Cachimbos dos Séculos XVII e XVIII do Palácio Mesquitela e Convento dos Inglesinhos (Lisboa)

Inês Simão / Marina Pinto / João Pimenta / Sara da Cruz Ferreira / André Bargão / Rodrigo Banha da Silva

1775 "Tomar os fumos da erua que chamão em Portugal erua sancta». Estudo de Cachimbos provenientes da Rua do Terreiro do Trigo, Lisboa

Miguel Martins de Sousa / José Pedro Henriques / Vanessa Galiza Filipe

1787 Cachimbos de Barro Caulínitico da Sé da Cidade Velha (República de Cabo Verde)

Rodrigo Banha da Silva / João Pimenta / Clementino Amaro

1801 Algumas considerações sobre espólio não cerâmico recuperado no Largo de Jesus (Lisboa) Carlos Boavida

1815 Adereços de vidro, dos séculos XVI-XVIII, procedentes do antigo Convento de Santana de Lisboa (anéis, braceletes e contas)

Joana Gonçalves / Rosa Varela Gomes / Mário Varela Gomes

1837 Da ostentação, luxo e poder à simplicidade do uso quotidiano: arqueologia e simbologia de joias e adornos da Idade Moderna Portuguesa Jéssica Iglésias

1849 Os amuletos em Portugal - dos objetos às superstições: o coral vermelho Alexandra Vieira

1865 Cerâmicas de Vila Franca de Xira nos séculos XV e XVI Eva Pires

1879 «Não passa por teu o que me pertence». Marcas de individualização associadas a faianças do Convento de Nossa Senhora de Aracoeli, Alcácer do Sal Catarina Parreira / Íris Fragoso / Miguel Martins de Sousa

1891 Cerâmica de Leiria: alguns focos de produção

Jaqueline Pereira / André Donas-Botto

1901 Os Fornos na Rua da Biquinha, em Óbidos Hugo Silva / Filipe Oliveira

1909 A casa de Pêro Fernandes, contador dos contos de D. Manuel I: o sítio arqueológico da Silha do Alferes, Seixal (século XVI) Mariana Nunes Ferreira

1921 O Alto da Vigia (Sintra) e a vigilância e defesa da costa Alexandre Gonçalves / Sandra Santos

1937 O contexto da torre sineira da Igreja de Santa Maria de Loures Paulo Calaveira / Martim Lopes

1949 A Necrópole do Hospital Militar do Castelo de São Jorge e as práticas funerárias na Lisboa de Época Moderna Susana Henriques / Liliana Matias de Carvalho / Ana Amarante / Sofia N. Wasterlain

1963 SAND - Sarilhos Grandes Entre dois Mundos: o adro da Igreja e a Paleobiologia dos ossos humanos recuperados

Paula Alves Pereira / Roger Lee Jesus / Bruno M. Magalhães

1975 Expansão urbana da vila de Cascais no século XVII e XVIII: a intervenção arqueológica na Rua da Vitória no 15 a 17

Tiago Pereira / Vanessa Filipe

1987 Novos dados para o conhecimento do Urbanismo de Faro em época Moderna Ana Rosa 
1995 Um exemplo de Arqueologia Urbana em Alcoutim: o Antigo Edifício dos CTT Marco Fernandes / Marta Dias / Alexandra Gradim / Virgílio Lopes / Susana Gómez Martínez

2007 Palácio dos Ferrazes (Rua das Flores/Rua da Vitória, Porto): a cocheira de Domingos Oliveira Maia

Francisco Raimundo

2021 As muitas vidas de um edifício urbano: História, Arqueologia e Antropologia no antigo Recreatório Paroquial de Penafiel Helena Bernardo / Jorge Sampaio / Marta Borges

2035 O convento de Nossa Senhora da Esperança de Ponta Delgada: o contributo da arqueologia para o conhecimento de um monumento identitário João Gonçalves Araújo / N’Zinga Oliveira

2047 Arqueologia na ilha do Corvo... em busca da capela de Nossa Senhora do Rosário Tânia Manuel Casimiro / José Luís Neto / Luís Borges / Pedro Parreira

2059 Perdidos à vista da Costa. Trabalhos arqueológicos subaquáticos na Barra do Tejo Jorge Freire / José Bettencourt / Augusto Salgado

2071 Arqueologia marítima em Cabo Verde: enquadramento e primeiros resultados do projecto CONCHA

José Bettencourt / Adilson Dias / Carlos Lima / Christelle Chouzenoux / Cristóvão Fonseca / Dúnia Pereira / Gonçalo Lopes / Inês Coelho / Jaylson Monteiro / José Lima / Maria Eugénia Alves / Patrícia Carvalho / Tiago Silva

2085 Trabalhos arqueológicos na Cidade Velha (Ribeira Grande de Santiago, Cabo Verde): reflexões sobre um projecto de investigação e divulgação patrimonial André Teixeira / Jaylson Monteiro / Mariana Mateus / Nireide Tavares / Cristovão Fonseca / Gonçalo C. Lopes / Joana Bento Torres / Dúnia Pereira / André Bargão / Aurélie Mayer / Bruno Zélie / Carlos Lima / Christelle Chouzenoux / Inês Henriques / Inês Pinto Coelho / José Lima / Patrícia Carvalho / Tiago Silva

2103 A antiga fortificação de Quelba / Khor Kalba (E.A.U.). Resultados de quatro campanhas de escavações, problemáticas e perspectivas futuras Rui Carita / Rosa Varela Gomes / Mário Varela Gomes / Kamyar Kamyad

2123 Colónias para homens novos: arqueologia da colonização agrária fascista no noroeste ibérico Xurxo Ayán Vila / José Mạ . Señorán Martín 


\title{
ALGUMAS CONSIDERAÇÕES SOBRE ESPÓLIO NÃO CERÂMICO RECUPERADO NO LARGO DE JESUS (LISBOA)
}

\author{
Carlos Boavida ${ }^{1}$
}

\begin{abstract}
RESUMO
Em 2005, a construção de um parque de estacionamento subterrâneo no Largo de Jesus, em Lisboa, levou à realização de uma intervenção arqueológica, num espaço que corresponde ao antigo adro da Igreja de Jesus, actual igreja paroquial das Mercês. Além de outros vestígios, ali foram identificadas as fundações de uma escadaria de acesso à igreja, assim como diversas estruturas murárias, ao que tudo indica, anteriores ao Terramoto de 1755 e relacionadas com uma zona de armazéns que poderiam ter pertencido ao palácio Mendia, a Oeste do largo e totalmente remodelado após o sismo. A intervenção permitiu também verificar que distintas obras de remodelação daquele espaço foram progressivamente eliminando as realidades espaciais anteriores, comprometendo e dificultando a sua leitura, pois afectaram daquele modo todos os contextos estratigráficos detectados.

São numerosos os vestígios das materialidades quotidianas que se encontravam naquelas realidades, com especial destaque para os recipientes cerâmicos; no entanto, é objectivo deste trabalho dar a conhecer alguns dos artefactos não cerâmicos ali recuperados.
\end{abstract}

Palavras-chave: Lisboa, Época Moderna, Artefactos não cerâmicos.

\begin{abstract}
The construction of an underground car park at Largo de Jesus, in Lisbon, led to an archaeological intervention in 2005. That space corresponds to the old churchyard of the Jesus' Church, the Mercês' current parish seat. In addition to other remains, the foundations of the staircase leading to the church were identified, as well as several wall structures. Some of those seem to be prior to the 1755 earthquake and related to an area of warehouses that could have belonged to the Mendia palace, on the west side of the square, completely remodeled after the earthquake. The intervention also made it possible to verify that different rebuilding works on that place eliminated, progressively, the previous spatial realities, affected it in all the stratigraphic contexts detected, compromising and hindering their reading.

There are numerous remains of everyday material that were found in those realities, with special emphasis on ceramic containers; however, the objective of this work is to present some of the non-ceramic artifacts recovered there.
\end{abstract}

Keywords: Lisboa, Modern Age, Non-ceramic artifacts.

\section{EVOLUÇÃO URBANA E A INTERVENÇÃO ARQUEOLÓGICA NO LARGO DE JESUS (2005)}

O Largo de Jesus, antigo adro da igreja daquela invocação, foi alvo de uma intervenção arqueológica no âmbito da construção de um parque de estacionamento subterrâneo em 2005. Aqueles trabalhos foram coordenados por Maria João Santos, então colaboradora da empresa GeoArque (Santos, 2005). A igreja e respectivo convento foram erguidos no final do século XVI, por iniciativa da Ordem Terceira de São Francisco, estando a obra concluída na centúria seguinte (Cardoso, 2004: 15-16). Junto da igreja foi também instituído um hospício que actualmente permanece em funcionamento como hospital (Figura 1A).

Através de uma imagem oitocentista anónima, pu-

1. IAP-FCSH/UNL; AAP. 
blicada por Ferreira de Andrade (1945: 95), é possível verificar que no adro da igreja, fronteiro à sua fachada principal, existia um pequeno escadório ladeado por volutas (Figura 1B). Embora aquela estrutura tenha sido demolida no século XIX devido a alterações à circulação no local, os trabalhos arqueológicos ocorridos em 2005 permitiram a identificação das suas fundações (Santos, 2007: 382; 2017: 192) (Figura 1C).

Estes vestígios encontravam-se sobre vários depósitos, muito revolvidos, que nivelaram a área do largo, onde existe uma pendente natural do terreno, principalmente do lado Este. Nestes níveis foi recuperado diverso espólio dos séculos XVII e XVIII, em muitos casos com evidências de exposição ao fogo, eventualmente relacionadas com os incêndios provocados na sequência do Terramoto de 1755 . Foram igualmente encontrados alguns restos osteológicos humanos desconexos (Santos, 2017: 192).

Após a remoção daqueles depósitos foram colocados à vista vários compartimentos constituídos por muros paralelos entre si, em alvenaria, muito provavelmente anteriores ao Terramoto de 1755 , associados aos quais foi recolhida grande quantidade de fragmentos de cerâmica de construção. Foram igualmente encontrados escassos restos de pavimento, assim como algumas talhas, evidência de uma possível área de armazéns que terá pertencido ao palácio $\mathrm{Mendia}^{2}$, a Oeste do largo, e que terá sido remodelado após o sismo (Santos, 2007: 389-392) (Figura 1D). Este palácio, cuja entrada seria feita pela então Rua Larga de Jesus (actual Rua dos Poiais de São Bento), foi residência de várias individualidades, entre os quais se destacam, no final do século XVII, o Desembargador Diogo Carvalho de Sequeira e, ao longo de quase toda a primeira metade do século XVIII, a família de Manuel Vasconcelos e Sousa. Este último, além de trinchante-mor do rei D. Pedro II, era filho do 2.. Conde de Castelo Melhor, irmão do $3 .^{\circ}$ titular dessa casa e também de D. António Vasconcelos e Sousa, que foi Bispo de Lamego e. mais tarde. de Coimbra (Flor, 2017).

A par das estruturas murárias referidas foi ainda identificado um depósito onde abundavam restos de revestimento e grelha de forno cerâmico, juntamente com loiça chacotada e várias trempes (Santos, 2007: 387-389; 2017:192-193). Estes achados deverão

2. Esta designação surge, a partir de 1861, quando José Matheo de Mendia y Elorza adquiriu o edifício. corresponder a olaria aqui existente, ou nas proximidades, em data anterior à construção do Palácio Mendia, pois o espólio que surge associado a estes vestígios remonta ao final do século XVI e meados do século XVII (Cardoso \& Batalha, 2017: 147-148; Santos, 2017: 193-194). A reorganização urbana que se verificou nesta zona com a fundação do Convento de Jesus terá levado à desactivação das olarias próximas (Cardoso \& Batalha, 2017: 161).

\section{ESPÓLIO ARQUEOLÓGICO RECUPERADO - PEQUENA SÍNTESE}

Apesar de várias intervenções ocorridas no Largo de Jesus terem progressivamente comprometido a leitura dos contextos ali existentes, as escavações arqueológicas de 2005 possibilitaram a identificação de vestígios de diversas estruturas. Além destas, embora os depósitos estratigráficos se encontrassem muito revolvidos, foi recuperado um importante conjunto de materiais, nomeadamente cerâmicos, nos contextos associados aos restos do forno. Foram igualmente recolhidos alguns numismas, na maioria, do reinado de D. Sebastião (Cardoso \& Batalha, 2017).

Nos outros contextos referidos foram encontrados também variados tipos cerâmicos (Sousa, 2007: 393399), assim como objectos em vidro, sendo estes últimos atribuídos aos finais do século XVI e primeira metade da centúria seguinte (Boavida, 2017a).

Além destes, embora em quantidades muito reduzidas (quando não apenas raros exemplares) foram recuperados também artefactos produzidos com ligas metálicas, distintas matérias de origem animal e azeviche.

\section{ARTEFACTOS METÁLICOS}

Os alfinetes e as agulhetas são os mais numerosos deste conjunto.

No caso dos primeiros (Figura 2A), trata-se de pequenas hastes de cobre às quais foi enrolado fio do mesmo material constituindo a cabeça. Além de poderem ter sido usados como elementos de vestuário, a sua presença é também comum em contextos funerários, pois eram frequentemente usados nos sudários (Boavida, 2016).

Em relação às agulhetas (Figura $2 \mathrm{~B}$ ), elas eram produzidas a partir de finas folhas de cobre, enroladas em formato afunilado, sendo depois aplicadas na 
ponta de atilhos. Alguns exemplares mostram marca de punção junto da extremidade mais larga, que permitia a fixação do fio no seu interior. Estes dois tipos de elementos de vestuário são normalmente encontrados em contextos arqueológicos portugueses atribuídos a cronologias entre os séculos XV e XVII (Fernandes \& Carvalho, 1997; Mourão, 2004; Nolen, 2004; Cardoso, 2007; Cardoso, 2008; Boavida, 2016; 2017b). Sendo peças de pequena dimensão, facilmente se dispersam surgindo muitas vezes fora de contexto. A sua presença é recorrente na iconografia da época, principalmente as agulhetas, que aparecem em quase todas as obras da Escola Portuguesa de Pintura dos séculos XV e XVI (Boavida, 2016). Tal facto é raro em relação aos alfinetes, em obras de autores portugueses, mas usual nas realizadas pela mão de pintores flamengos, onde podem ser vistos a auxiliar a fixação de véus e toucados (Boavida, 2016). Além desta função, este tipo de alfinetes pode estar igualmente relacionados com actividades como a costura, em particular quando são encontrados em associação com dedais (Nolen, 2004), que também foram recolhidos no Largo de Jesus, mas não nos mesmos contextos estratigráficos. Estes objectos (Figura ${ }_{2} \mathrm{C}$ ), de cobre, têm formato cónico com a extremidade distal plana. Normalmente são usados como auxiliar para empurrar agulhas ou alfinetes na perfuração dos tecidos a coser, tendo a superfície externa, quase sempre, preenchida na totalidade por pequenas concavidades que evitam que a cabeça daqueles deslize sobre a superfície do dedal. Servem igualmente para proteger a cabeça do dedo de eventuais picadas.

Os seis dedais encontrados no Largo de Jesus estão muito danificados, apresentando todos evidências de esmagamento, estando três totalmente esmagados e desfeitos. São idênticos a um outro presente no painel da "Anunciação" que integra o retábulo da Sé de Viseu, atribuído a Francisco Henriques (?-1518) e Vasco Fernandes (1475-1542) (Henriques, 2010) (Figura 4A).

Foi recolhido também parte de um pequeno colchete de cobre (Figura 2D). Estes elementos de vestuário, normalmente em pares, sendo a fêmea em forma de argola e o macho em formato de gancho, articulam-se entre si para prender diferentes partes do vestuário. No caso do Largo de Jesus trata-se um colchete fêmea.

Entre os artefactos metálicos colectados no âmbito da intervenção arqueológica estão igualmente dois que se podem classificar como objectos sonoros. São eles um fragmento de guizo e um címbalo, ambos de cobre.

O guizo (Figura 2E), do qual só se preserva um quarto da peça, correspondendo aquela a metade de uma das meias esferas que o constitui. Apresenta a superfície externa dividida em quartos, por pequena nervura, tendo aqueles uma perfuração na zona central. Este tipo de objecto poderia ter distintas funções. Embora o seu uso possa estar relacionado com a falcoaria, os guizos também surgem associados às vestimentas de alguns clérigos, pois existia a convicção de que o som provocado por estes afastava os maus espíritos (Deagan, 2002: 140). Veja-se a esse propósito alguns retábulos portugueses do século XVI que se encontram nas colecções do Museu Nacional de Arte Antiga, nomeadamente os provenientes do Convento de Santa Joana (Lisboa) e da Ermida de Nossa Senhora do Paraíso (Lisboa), respectivamente da autoria de Garcia Fernandes (1514-1565) e de Gregório Lopes (1490-1550) (Figuras 4B/4C).

Tal como os colchetes, os címbalos (Figura $2 \mathrm{~F}$ ) também funcionam mediante a presença de um par, ou associados a pandeiretas, que eram usados tanto em cerimónias religiosas como profanas (Boavida, 2017b).

No âmbito de um outro trabalho sobre objectos metálicos usados na cozinha e à mesa, foi publicado preliminarmente um fragmento de eventual escumadeira de cobre recolhido no Largo de Jesus (Boavi$\mathrm{da}, 2017 \mathrm{c}$ ) (Figura 2H). Devido à sua fragilidade, pois trata-se de fina folha metálica, redonda e algo côncava, com várias perfurações, são raros os achados desta forma em contexto arqueológico. A sua presença é frequente em diversas pinturas flamengas, dos séculos XVI e XVII, tanto em naturezas-mortas como em cenas que mostram espaços de cozinha, como por exemplo "Natureza morta com peixe e gato" de Wallerant Vaillant (1623-1677) (Boavida, 2017c: 128) (Figura 4D).

No que diz respeito aos utensílios de cozinha, a colecção de objectos metálicos do Largo de Jesus inclui também um elemento de cabo de faca (Figura $2 \mathrm{G}$ ). Trata-se peça de cobre, de formato sub-hemisférico, que era colocada entre o cabo, provavelmente de madeira, e a lâmina da faca. Ao centro, mostra incisão triangular onde encaixava o espigão de fixação daquela ao cabo. É quase sempre esta a forma básica de uma faca, com uma lâmina de secção sub-triangular e formato idêntico alongado, por vezes com a ponta 
arredondada. Este utensílio extramente versátil, com poucas variações desde a Antiguidade, também surge por vezes com cabo metálico na continuidade da lâmina, no qual, por meio de rebites, são fixados peças de madeira ou outros materiais mais nobres como marfim, madrepérola ou diferentes pedras duras.

São conhecidos vários exemplares de facas desta cronologia na região de Lisboa, alguns com peças de madeira aplicada no cabo, onde se destaca a colecção de objectos metálicos de Carnide (Boavida, 2017b: 1824 e 1832, figs. 5A-5B). As facas são um objecto recorrente, normalmente sobre mesas, na iconografia de várias escolas de pintura europeias. Veja-se a esse propósito o já citado retábulo de № . $\mathrm{Sr}^{\mathrm{a}}$. do Paraíso (Figura 4 F). No painel da "Última Ceia", do retábulo do Convento de São Francisco (Évora), há uma personagem que usa uma faca para palitar os dentes (Figura 4E). Peças idênticas surgem também em obras de Josefa d'Ayala Figueira ${ }^{3}$ (1630-1684), de Diego Velásquez (1599-1660), de António de Pereda (1611-1678), de Georg Flegel (1566-1638) e de Jan Steen (1626-1679), só para citar alguns exemplos de várias escolas de pintura europeias (Figuras 4G-4K). Entre as peças de vidro encontradas neste arqueossítio foi identificado o gargalo de garrafa quadrangular cuja tampa seria em chumbo, como atestam os restos de rosca naquela matéria (Boavida, 2017a). Estas tampas de chumbo normalmente apresentavam na parte superior uma pequena argola, fixa por meio de um espigão, que se articula com outra argola de maior dimensão. Entre os artefactos metálicos recolhidos está precisamente um espigão deste tipo com as respectivas argolas (Figura 2I). Provavelmente estas argolas estavam associadas a uma corrente pendente da rosca, impossibilitando assim a perda da tampa. Exemplares deste tipo podem ser vistos em pinturas de origem flamenga, como "Natureza morta com instrumentos musicais" de Pieter Claesz (1597-1661) (Figura 4N).

Foram ainda recuperados outros elementos, de cobre, que terão pertencido a peças de mobiliário, a saber, três pregos de forro de cadeira (Figuras 2J-2L), um provável puxador (Figura $2 \mathrm{M}$ ) e fragmento de uma dobradiça (Figura $2 \mathrm{~N}$ ).

A dobradiça é exactamente igual a outras duas encontradas em Carnide, estando uma daquelas completa ao contrário de o exemplar agora apresentado (Boavida, 2017b: 1823). Trata-se de um elemento que

3. Dita Josefa d'Óbidos. seria provavelmente de um armário copeiro ou de outra peça de mobiliário de algum aparato. Os eixos de fixação, tal como nas dobradiças de Carnide, encontram-se dobrados, permitindo perceber qual a espessura das tábuas de madeira que constituíam o móvel.

Entre os objectos metálicos foram ainda recolhidas algumas aparas de cobre, assim como duas peças em chumbo cuja função não foi possível determinar.

\section{ARTEFACTOS EM OSSO, MARFIM, MADREPÉROLA E AZEVICHE}

Neste grupo está incluída uma série de objectos frequentemente raros em contextos arqueológicos, uma vez que as matérias em que são produzidos são muito perecíveis. Subsistem no entanto, em colecções museológicas, exemplares bem conservados, na maioria dos casos completos, que dizem respeito a objectos vistos como coleccionáveis por quem os adquiriu e não para uso quotidiano.

Em osso foram recuperados quatro conjuntos de pequenos elementos cilíndricos, algo facetados, com um acabamento pouco regular, como se o seu talhe não tivesse sido concluído (Figura 3A). Uma das pontas é totalmente plana, como que truncada, enquanto a outra é algo desbastada, em cunha, talvez para permitir a sua fixação em embutido em peças de mobiliário, como por exemplo as designadas cadeiras de braços de Mombaça (Henriques, 2003: 144; Dias, 2004: 18). Estas peças de embutir surgem muitas vezes também em marfim, matéria em que existem também dois elementos com idênticas características aos produzidos em osso, mas ambas as extremidades são truncadas e o acabamento é de muito melhor qualidade. Um deles é substancialmente maior que todos os outros.

Um destes elementos mostra numa das extremidades uma pequena protuberância, muito provavelmente realizada ao torno. É pouco provável que este tenha tido a função que aqui se atribuí aos demais, embora também não se possa excluir a hipótese de que todos estes elementos tenham tido função distinta, que não foi possível aferir. $\mathrm{O}$ seu aspecto irregular, como referido anteriormente, pode indicar que se trata de peças inacabadas, possível evidência da existência de pequena oficina artesanal de talhe de objectos/elementos em osso que funcionaria no Largo de Jesus, ou nas suas proximidades. Da segunda metade do século XVI, é conhecida a presen- 
ça de oficina de talhe de objectos em osso na antiga prisão do Aljube (Ferreira, 2005/2006). Uma outra oficina, oitocentista, foi localizada no Largo da Atafona, onde se produziam maioritariamente botões (Vieira et al., 2019).

Também em osso foi recolhido uma empunhadura (Figura 3 B). A sua pequena dimensão prossupõe que seria de um talher, talvez o cabo de uma faca ou garfo. De secção sub-quadrangular, apresenta decoração incisa na face externa em padrão de losangos, no centro dos quais está um pequeno círculo com ponto central, ambos provavelmente obtidos com recurso a punção. Só se preserva, muito danificada, metade desta peça.

Um outro fragmento de talher, neste caso em marfim, que poderá ter sido uma colher ou garfo, mostra cabeça e parte do pescoço de uma ave de pico longo e ligeiramente entreaberto (Figura ${ }_{3} \mathrm{C}$ ). O corpo e a cabeça, onde sobressaem dois olhos circulares, são preenchidos por recticulado inciso reproduzindo as penas. Objectos deste tipo, produzidos nesta matéria, são referidos em diversa documentação alfandegária, em crónicas e inventários, ao longo de grande parte do século XVI e da centúria seguinte, provindos de regiões que hoje fazem parte da Serra Leoa e do Benim (Bassani \& Fagg, 1988: 59-6o). A primeira referência inequívoca a colheres vindas daquele último território remonta a 1588, sendo então descritas como peculiares colheres feitas a partir de dente de elefante, de diversos tamanhos, decoradas comvariados animais e aves; no entanto, colheres com estas características já se encontravam presentes, pelo menos desde 1560, em algumas colecções europeias (Bassani \& Fagg, 1988: 150).

Trabalhos de reclassificação dos marfins afro-portugueses nas colecções etnográficas do Museu Britânico, nos anos 50/6o do século XX, levaram a que algumas peças que apresentavam semelhanças com outros objectos artesanais provindos do Benim, fossem então designados como Bini-Portuguesas (Bassani \& Fagg, 1988: 150).

Tratando-se de uma produção artesanal, não há peças iguais entre si, embora alguns dos elementos escultóricos se repitam. É o caso de colheres de marfim presentes nas colecções do Museu Etnológico de Dresden ou dos Museus Estatais de Braunschweig, ambos na Saxónia, em cujo cabo surge ave de bico longo, algo entreaberto, como no exemplar encontrado no Largo de Jesus (Bassani \& Fagg, 1988: 242245 , figs. 137, 142, 148 e 166). As três primeiras aqui referidas pertenciam à colecção do Príncipe Christian da Saxónia, tendo sido registadas em 1590 e a última surge pela primeira vez em 1805, no inventário da Câmara de Maravilhas do Duque que então governava aquele estado germânico.

Talvez com idêntica origem, subsiste um pequeno fragmento de marfim, com algumas linhas incisas, que parece ter constituído parte de figura de vulto, talvez integrada em saleiro, mas a sua forma pouco clara não permite outras considerações (Figura 4D). Igualmente em marfim, mas com origem distinta, foi colectado um pequeno bordão de peregrino de Santiago de Compostela (Figura 3E). Trata-se de pequena haste, trabalhada ao torno, o que criou vários conjuntos de caneluras. Tal como as conchas de vieira (Pecten maximus) também estes pequenos objectos eram colocados nos chapéus e na roupa dos romeiros. Vários exemplares podem ser vistos na indumentária de Stephan Praun III, peregrino alemão que viveu na segunda metade do século XVI, que integra a colecção do Museu Nacional Germânico de Nuremberga (Franco Mata, 1986: 133 e 145, figs. 1 e 6). Um outro chapéu, actualmente no Museu de Poznań, e que terá pertencido a peregrino polaco do século XVII, mostra vários pequenos bordões em marfim, juntamente com outros símbolos compostelanos (Franco Mata, 2005: 180 e 201, fig. 24).

Também a iconografia alusiva a esta temática mostra por vezes a utilização deste elemento associado aos peregrinos. É o caso da tela seiscentista intitulada "Menino Jesus vestido de romeiro de Santiago", de eventual discípulo de Josefa de Óbidos ${ }^{4}$, que se encontra no Museu de Aveiro, onde podem ver-se no manto alguns exemplares (Figura $4 \mathrm{O}$ ). $\mathrm{O}$ mesmo sucede no chapéu do próprio Santiago, que surge a abençoar uma freira dominicana, numa obra da oficina de Mestre Hilário ${ }^{5}$ (Coimbra), na colecção do mesmo museu, atribuída ao início do século XVI (Figura $4 \mathrm{P}$ ). Numa das pinturas de um retábulo, da primeira metade daquela centúria, da autoria dos Mestres de Ferreirim, que se guarda no Museu Nacional Machado de Castro, surgem São Simão e São Tiago Maior. No chapéu deste último, junto da concha de vieira, estão dois pequenos bordões cruzados (Figura 4Q).

\footnotetext{
4. Informação conforme Matriznet (consultado em Junho 2020).

5. Informação conforme Matriznet (consultado em Junho 2020).
} 
A Arqueologia também já permitiu identificar peça deste tipo. Foi encontrada, a par com duas conchas de vieira e uma miniatura de cabaça, junto da cabeça de um peregrino, do século XVI, sepultado no cemitério da igreja de Saint-Martin de Vevey, na Suiça (Picod, 2018: 42, fig. 2).

Recuperaram-se no Largo de Jesus mais três peças em marfim. Uma delas é uma pequena ficha de jogo (Figura $3 \mathrm{G}$ ), de formato circular, semelhante a outras encontradas no Convento de Sant'Ana, em Lisboa (Gomes, Gomes \& Gonçalves, 2017: 96).

Outra, tendo em conta o seu diâmetro e espessura, parece corresponder a fragmento de seringa de lavagens (Figura $3 \mathrm{H}$ ), também com paralelos naquele último arqueossítio (Gomes, Gomes \& Gonçalves, 2017: 92), assim como em peça de idêntica função da qual foram recolhidos vestígios num contexto associado ao Hospital Real de Todos-os-Santos (Boavida, 2017d: 447). Este instrumento é normalmente constituído por várias partes que encaixam entre si por meio de roscas, como as que se podem observar na face interna do exemplar do Largo de Jesus.

Existe também uma pequena colher, plana e muito fina (Figura $3 \mathrm{~F}$ ). A extremidade distal mostra pequena concha côncava, enquanto na extremidade proximal existe uma perfuração que certamente permitia a sua fixação, por meio de corrente, a uma caixa de rapé.

Produzido em madrepérola, a colecção incluí também um fragmento de uma travessa de cabelo, nomeadamente um dente de um destes adornos (Figura $\left.{ }_{3} \mathrm{I}\right)$.

No Largo de Jesus foi ainda recolhido um pequeno fragmento em azeviche (Figura 3J). Aquele apresenta formato espiralado, afilado na ponta, enquanto a outra extremidade está fracturada. Visto que não existe qualquer tipo de perfuração, não parece tratar-se uma conta.

Usado contra o mau-olhado, o azeviche surge frequentemente utilizado em figas, como as que foram encontradas em Santarém (Arruda, Viegas \& Almeida, 2002: 202), Coimbra (Mourão, 2004: 144) e Montemor-o-Novo ${ }^{6}$. Também na iconografia a sua presença é constante em retratos de crianças, juntamente com outros amuletos, tendo como objectivo

6. Cf. "Um objecto, uma história, mês a mês” (Março 2012), Programa do Castelo - Oficina de Arqueologia do Centro Interpretativo do Castelo de Montemor-o-Novo, flyer 9. proteger aquelas. Vejam-se a este propósito os retratos das infantes Ana Maria Maurícia e Margarida Francisca, filhas de Filipe III de Espanha, ambos da primeira década do século XVII, pintados, respectivamente por Juan Pantoja de la Cruz (1553-16o8) e Santiago Morán (1571-1626).

Embora o exemplar agora analisado não tenha o formato de uma figa, tal não invalida que possa ter integrado um pingente, engastado em metal precioso, como sucede amiúde com pontas de coral, exactamente com o mesmo objectivo, como mostram os retratos mencionados.

\section{CONSIDERAÇÕES FINAIS}

A área onde se localiza actualmente o Largo de Jesus encontrava-se na periferia da cidade de Lisboa até a meados do século XVI. A construção a Igreja de Jesus nas últimas décadas daquela centúria despoletou a integração daquele espaço na urbe, que há muito tinha ultrapassado os limites das suas muralhas, como evidencia a urbanização do vizinho Bairro Alto de São Roque (a leste) a partir de 1513.

No âmbito dos trabalhos arqueológicos realizados em 2005 no Largo de Jesus foram identificadas evidências dessas alterações, assim como também da evolução espacial daquele local. Verificou-se assim a desactivação de estruturas que deram lugar a outras, por iniciativa humana ou em resultado de catástrofes naturais, como o Terramoto de 1755 e os incêndios que lhe sucederam.

No que diz respeito ao espólio recolhido, aquele foi atribuído a um período cronológico que se estende de finais do século XVI até meados do século XVIII, data em que a ocupação do espaço se altera completamente, com a nivelação daquele para a criação do largo propriamente dito. Entre aquelas materialidades, além das habituais cerâmicas, estão alguns, raros, artefactos não cerâmicos, onde se destacam os produzidos em ligas metálicas e matérias de origem animal, nomeadamente em osso e marfim.

$\mathrm{Na}$ maioria dos casos trata-se de objectos quotidianos comuns a outros contextos arqueológicos conhecidos para estas cronologias, no entanto, outros há que são pouco frequentes. É o caso dos fragmentos de talheres em osso e marfim, que denunciam a presença de comunidades algo abastadas, provavelmente os ocupantes do Palácio Mendia. Seriam também esses os eventuais proprietários de mobiliário decorado com elementos na mesma matéria, 
caso estes não sejam provindos de possível oficina artesanal localizada nas proximidades.

Digno de nota é igualmente o pequeno bordão de peregrino, pois reflecte um aspecto das mentalidades da época. A questão que fica em aberto em relação a este objecto é se ele pertencia a algum dos residentes na zona ou se foi perdido por algum romeiro que tenha passado por aqui.

\section{AGRADECIMENTOS}

Guilherme Cardoso, António Marques, Nathalie Antunes-Ferreira, Joana Gonçalves, Edgar Fernandes e João Pedro Boavida pelos esclarecimentos sobre diversos aspectos, assim como a indicação e cedência de alguma bibliografia.

Centro de Arqueologia de Lisboa - CML pela cedência do espólio para o seu estudo e publicação.

\section{BIBLIOGRAFIA}

“Um objecto, uma história, mês a mês" (Março 2012). Programa do Castelo - Oficina de Arqueologia do Centro Interpretativo do Castelo de Monte-o-Novo. Montemor-o-Novo: Câmara Municipal (flyer 9).

ANDRADE, Ferreira de (1945) - A Igreja de Nossa Senhora de Jesus. Olisipo - Boletim do Grupo Amigos de Lisboa, 30. Lisboa: Grupo Amigos de Lisboa, pp. 85-99.

ARRUDA, Ana Margarida; VIEGAS, Catarina; ALMEIDA, Ma․ José (coord.) (2002) - Scallabis a Santarém (catálogo da exposição no Museu Nacional de Arqueologia). Lisboa: Museu Nacional de Arqueologia / Instituto Português dos Museus.

BASSANI, Ezio; FAGG, William Buller (1988) - Africa and the Renaissance: Art in Ivory. New York: The Center for African Art / Prestel-Verlag.

BOAVIDA, Carlos (2016) - "Objectos de uso pessoal medievais e modernos no castelo de Castelo Branco" in VILAÇA, R. (coord.) Actas do II Congresso Internacional de Arqueologia da Região de Castelo Branco. Castelo Branco: Sociedade dos Amigos do Museu de Francisco Tavares Proença Júnior, pp. 391-405.

BOAVIDA, Carlos (2017a) - "Entre copos e garrafas. Os vidros do Largo de Jesus" in SENNA-MARTINEZ, J. C.; MARTINS, A. C.; MELO, A. A.; CAESSA, A.; MARQUES, A.; CAMEIRA, I. (edit.) Diz-me o que comes. . Alimentação antes e depois da cidade (Fragmentos de Arqueologia de Lisboa 1). Lisboa: Centro de Arqueologia de Lisboa / Câmara Municipal de Lisboa, Secção de Arqueologia / Sociedade de Geografia de Lisboa, pp. 131-137.

BOAVIDA, Carlos (2017b) - "Dos objectos inúteis, esquecidos ou perdidos. Os artefactos metálicos do Largo do Coreto
(Carnide, Lisboa)" in ARNAUD, J. M.; MARTINS, A. (edit.) Arqueologia em Portugal. 2017 - Estado da Questão. Lisboa: Associação dos arqueólogos Portugueses, pp. 1821-1834.

BOAVIDA, Carlos (2017c) - "Preparar, servir e comer. Vestígios arqueológicos metálicos do que se usava na cozinha e à mesa na Lisboa Moderna. Uma primeira abordagem" in SENNA-MARTINEZ, J. C.; MARTINS, A. C.; MELO, A. A.; CAESSA, A.; MARQUES, A.; CAMEIRA, I. (edit.) Diz-meo que comes. . Alimentação antes e depois da cidade (Fragmentos de Arqueologia de Lisboa 1). Lisboa: Centro de Arqueologia de Lisboa / Câmara Municipal de Lisboa, Secção de Arqueologia / Sociedade de Geografia de Lisboa, pp. 122-130.

BOAVIDA, Carlos (2017d) - “Objectos do quotidiano num poço do Hospital Real de Todos-os-Santos” in CAESSA, A.; NOZES, C.; CAMEIRA, I.; SILVA, R. B. (coord.) Uma cidade em escavação. Actas do I Encontro de Arqueologia de Lisboa. Lisboa: Centro de Arqueologia de Lisboa - Câmara Municipal de Lisboa, pp. 440-457.

CARDOSO, Guilherme (2007) - A Igreja de Nossa Senhora da Conceição do Cadaval. Arqueologia do Cadaval, 3. Cadaval: Câmara Municipal.

CARDOSO, Guilherme; BATALHA, Luísa (2017) - "Evidências de produção oleira dos finais do século XVI a meados do século XVII no Largo de Jesus (Lisboa)" in CAESSA, A.; NOZES, C.; CAMEIRA, I.; SILVA, R. B. (coord.) Uma cidade em escavação. Actas do I Encontro de Arqueologia de Lisboa. Lisboa: Centro de Arqueologia de Lisboa - Câmara Municipal de Lisboa, pp. 146-181.

CARDOSO, João Luís (2008) - Resultados das escavações arqueológicas no claustro do antigo Convento de Jesus (Academia das Ciências de Lisboa) entre Julho e Dezembro de 2004. Revista Portuguesa de Arqueologia 11:1. Lisboa: Instituto Português de Arqueologia, pp. 259-284.

CARDOSO, M. F. V. (2004) - De templo conventual de Nossa Senhora de Jesus a Paróquia de Nossa Senhora das Mercês. Lisboa: Paróquia de Nossa Senhora das Mercês.

DEAGAN, Kathleen (2002) - Artifacts of the Spanish Colonies of Florida and the Caribbean, 150o-18oo - vol. II: Portable personal possessions. [S.1.]: Smithsonian Institution Press.

DIAS, Pedro (2004) - A Arte do Marfim. O mundo onde os portugueses chegaram. Porto: V. O. C. Antiguidades, Lda.

FERNANDES, Isabel Cristina; CARVALHO, Ant.ำ Rafael (1997) - Intervenção arqueológica na Rua de Nenhures (área urbana de Palmela). Setúbal Arqueológica 11/12. Setúbal: Museu de Arqueologia e Etnografia, Assembleia Distrital de Setúbal, pp. 279-295.

FERREIRA, A. Rita M. (2005/2006): Arqueozoologia num contexto prisional: Métodos e técnicas de trabalho do osso utilizados na prisão do Aljube-Lisboa na segunda metade do Século XVI. Dissertação de Mestrado em Quaternário e Pré-História, apresentada à Universidade de Trás-os-Montes e Alto Douro (policopiado, não publicado). 
FLOR, Pedro (2017) - "Palácio de Manuel Vasconcelos e Sousa" in FLOR, P. (coord.) Lisboa em Azulejo antes do Terramoto de 1755. Lisboa: Instituto de História da Arte da Faculdade de Ciências Sociais e Humanas da Universidade NOVA de Lisboa (http://lisboaemazulejo.fcsh.unl.pt, consultado em Maio 2020).

FRANCO MATA, Ángela (2005) - “Iconografía jacobea en azabache" in Lacarra Ducay, M. C. (coord.) Los caminos de Santiago. Arte, Historia y Literatura. [S.1.]: Instituto Fernando el Católico, pp.169-212.

FRANCO MATA, María Ángela (1986) - Azabaches del M.A.N.. Boletín del Museo Arqueológico Nacional, Tomo IV -2. Madrid: Museo Arqueológico Nacional, pp. 131-167.

GOMES, Mário Varela; GOMES, Rosa Varela; GONÇALVES, Joana (2017) - "Objectos produzidos em matérias duras de origem animal, do Convento de Santana, de Lisboa" in CAESSA, A.; NOZES, C.; CAMEIRA, I.; SILVA, R. B. (coord.) Uma cidade em escavação. Actas do I Encontro de Arqueologia de Lisboa. Lisboa: Centro de Arqueologia de Lisboa - Câmara Municipal de Lisboa, pp. 84-105.

HENRIQUES, Ana de Castro (2003) - Museu Nacional de Arte Antiga. Roteiro. Lisboa: Instituto Português dos $\mathrm{Mu}-$ seus / Edições Asa.

HENRIQUES, Ana de Castro (coord.) (2010) - Os Primitivos Portugueses 1450-1550. O Século de Nuno Gonçalves (catálogo da exposição no Museu Nacional de Arte Antiga). Lisboa: Museu Nacional de Arte Antiga / Athena.

MOURÃO, Teresa P. S. M. (2004) - Entre murmúrios e orações: Aspectos da vida quotidiana do Convento de Santa-Clara-a-Velha captados através do espólio funerário (séc. XVI e XVII). Vol. II - Anexos. Dissertação de Mestrado em Museologia e Património Cultural apresentada à Faculdade de Letras da Universidade de Coimbra (policopiado, não publicado).

NOLEN, Jeanette U. S. (2004) - Museu de Arqueologia do Castelo de Vila Viçosa (roteiro). Vila Viçosa: Fundação da Casa de Bragança.

PICOD, C. (2018) - Le tournage 'l'archet d'un bourdon de pèlerinage miniature en os: experimentation par un Tourneur marocain. Instrumentum, 47. Chauvigny: Musées de Chauvigny, pp. 43-47.

SANTOS, Ma․ João (2005) - Sondagens arqueológicas no Largo de Jesus (freguesia das Mercês, Lisboa). Relatório Final. [S.1.]: GeoArquE - Consultores na Área do Património Cultural, Lda. (98 p. + 130 est.) (policopiado, não publicado).

SANTOS, Mํa João (2007) - Largo de Jesus: contributo para a história incógnita de Lisboa antiga. Revista Portuguesa de Arqueologia, 10.1. Lisboa: Instituto Português de Arqueologia, pp. 381-399.

SANTOS, Ma․ João Correia (2017) - "Pavimentos antigos no Largo de Jesus (Mercês, Lisboa)" in BUGALHÃO, J.;
FERNANDES, L.; FERNANDES, P. A. (coord.) Debaixo dos Nossos Pés (catálogo da exposição no Museu de Lisboa/ Torreão Poente). Lisboa: EGEAC/Museu de Lisboa - CML, pp. 192-196.

VIEIRA, Vasco; CASIMIRO, Tânia Manuel; FILIPE, Vanessa; DETRY, Cleia (2019) - "Vamos falar com os nossos botões. Uma oficina do século XIX na Mouraria” in SENNA-MARTINEZ, J. C.; MARTINS, A. C.; CAESSA, A.; MARQUES, A.; CAMEIRA, I. (edit.) Extrair e produzir... Dos primeiros artefactos à industrialização (Fragmentos de Arqueologia de Lisboa 3). Lisboa: Centro de Arqueologia de Lisboa/Câmara Municipal de Lisboa, Secção de Arqueologia/Sociedade de Geografia de Lisboa, pp. 133-140.

\section{DOCUMENTAÇÃO ICONOGRÁFICA}

Autor desconhecido (séc. XVII) - "Menino Jesus vestido de romeiro de Santiago" (Museu de Aveiro, Aveiro). Disponível em http://www.matriznet.dgpc.pt/MatrizNet/Objectos/ ObjectosConsultar.aspx?IdReg=97234 (consultado em Junho 2020).

BARCO, Gabriel del (c. 1750) - "Grande panorama de Lisboa" (Museu Nacional do Azulejo, Lisboa). Disponível em http:// www.matriznet.dgpc.pt/MatrizNet/Objectos/ObjectosConsultar.aspx?IdReg=228321 (consultado em Junho 2020).

CLAESZ, Pieter (1623) - "Still life with musical instruments" (Musée du Louvre, Paris). Disponível em http://www.the-athenaeum.org/art/display_image.php?id=449698 (consultado em Dezembro 2016).

FERNANDES, Garcia (1538) - "Retábulo do Convento de $S t^{\underline{a}}$. Joana” (Museu Nacional de Arte Antiga, Lisboa). Disponível em http://www.matriznet.dgpc.pt/MatrizNet/Objectos/ObjectosConsultar.aspx?IdReg=250093 (consultado em Junho de 2020).

FERREIRIM, Mestres de (1525/1550) - "São Simão e São Tiago Maior / Apostolado de Ferrerim” (Museu Nacional Machado de Castro, Coimbra). Disponível em http://www. matriznet.dgpc.pt/MatrizNet/Objectos/ObjectosConsultar. aspx?IdReg=1582988 (consultado em Junho 2020).

FIGUEIRA, Josefa Ayala (166o/1670) - “Natureza morta: caixas, barros eflores" (Museu Nacional de Arte Antiga, Lisboa). Disponível em http://www.matriznet.dgpc.pt/MatrizNet/Objectos/ObjectosConsultar.aspx?IdReg=250995 (consultado em Novembro 2016).

FLEGEL, Georg (1635) - "Still life with stag bettle" (WallrafRichartz-Museum \& Fondation Corboud, Koln). Disponível em http://www.the-athenaeum.org/art/display_image. php?id=384787 (consultado em Novembro 2016).

HENRIQUES, Francisco (1508/1511) - “Retábulo da Igreja de São Francisco de Évora" (Museu Nacional de Arte Antiga, Lisboa). Disponível em http://www.matriznet.dgpc.pt/ MatrizNet/Objectos/ObjectosConsultar.aspx?IdReg= 248469 (consultado em Novembro 2016). 
HENRIQUES, Francisco; FERNANDES, Vasco (1501/o6) "Políptico da Capela-Mor da Sé de Viseu" (Museu Grão Vasco, Viseu). Disponível em http://www.matriznet.dgpc.pt/ MatrizNet/Objectos/ObjectosConsultar.aspx?IdReg=207599 (consultado em Outubro 2017).

HILÁRIO, Oficina de Mestre (1505) - "Santiago abençoando uma freira dominicana" (Museu de Aveiro, Aveiro). Disponível em http://www.matriznet.dgpc.pt/MatrizNet/Objectos/ObjectosConsultar.aspx?IdReg=97205 (consultado em Junho 2020).

LOPES, Gregório (1523?) - “Retábulo da Ermida de NNa . Sr ․ do Paraíso” (Museu Nacional de Arte Antiga, Lisboa). Disponível em http://www.matriznet.dgpc.pt/MatrizNet/Objectos/ ObjectosConsultar.aspx?IdReg=247959 (consultado em Novembro 2016).

MORÁN, Santiago (1610) - "Retrato de la infanta Margarita Francisca (1610-1616), hija de Felipe III” (Museo del Prado, Madrid). Disponível em https://commons.wikimedia.org/ wiki/File:Retrato_de_la_infanta_Margarita_Francisca_ (1610-1616),_hija_de_Felipe_III.jpg (consultado em Junho 2020).

PANTOJA DE LA CRUZ, Juan (1602) - "La infanta Ana Mauricia de Austria" (Convento de Las Descalzas Reales, Madrid). Disponível em https://commons.wikimedia.org/ wiki/File:Juan_Pantoja_de_la_Cruz_o2o.jpg (consultado em Junho 2020).

PEREDA Y SALGADO, Antonio de (1650/55) - “Two figures at a table with kitchen utensils" (Penrhyn Castle, Gwynedd). Disponível em http://www.nationaltrustcollections. org.uk/object/1421752 (consultado em Outubro 2017).

STEEN, Jan (1661) - "The Satyr and the Peasant Family" (J. Paul Getty Museum, Los Angeles). Disponível em https:// commons.wikimedia.org/wiki/File:Jan_Steen_(Dutch_-_The _and_the_Peasant_Family_-_Google_Art_Project.jpg (consultado em Outubro 2017).

VAILLANT, Wallerant (1640/166o) - "Still life with fish and cat" (Boijmans van Beuningen Museum, Roterdam). Disponível em http://www.the-athenaeum.org/art/full. php?ID=102054 (consultado em Dezembro 2016).

VELÁZQUEZ, Diego (1618) - "Vieja friendo huevos" (National Galleries of Scotland, Edimburg). Disponível em https://www.wikiart.org/pt/diego-velazquez/an-old-woman-cooking-eggs-1618 (consultado em Outubro 2017). 

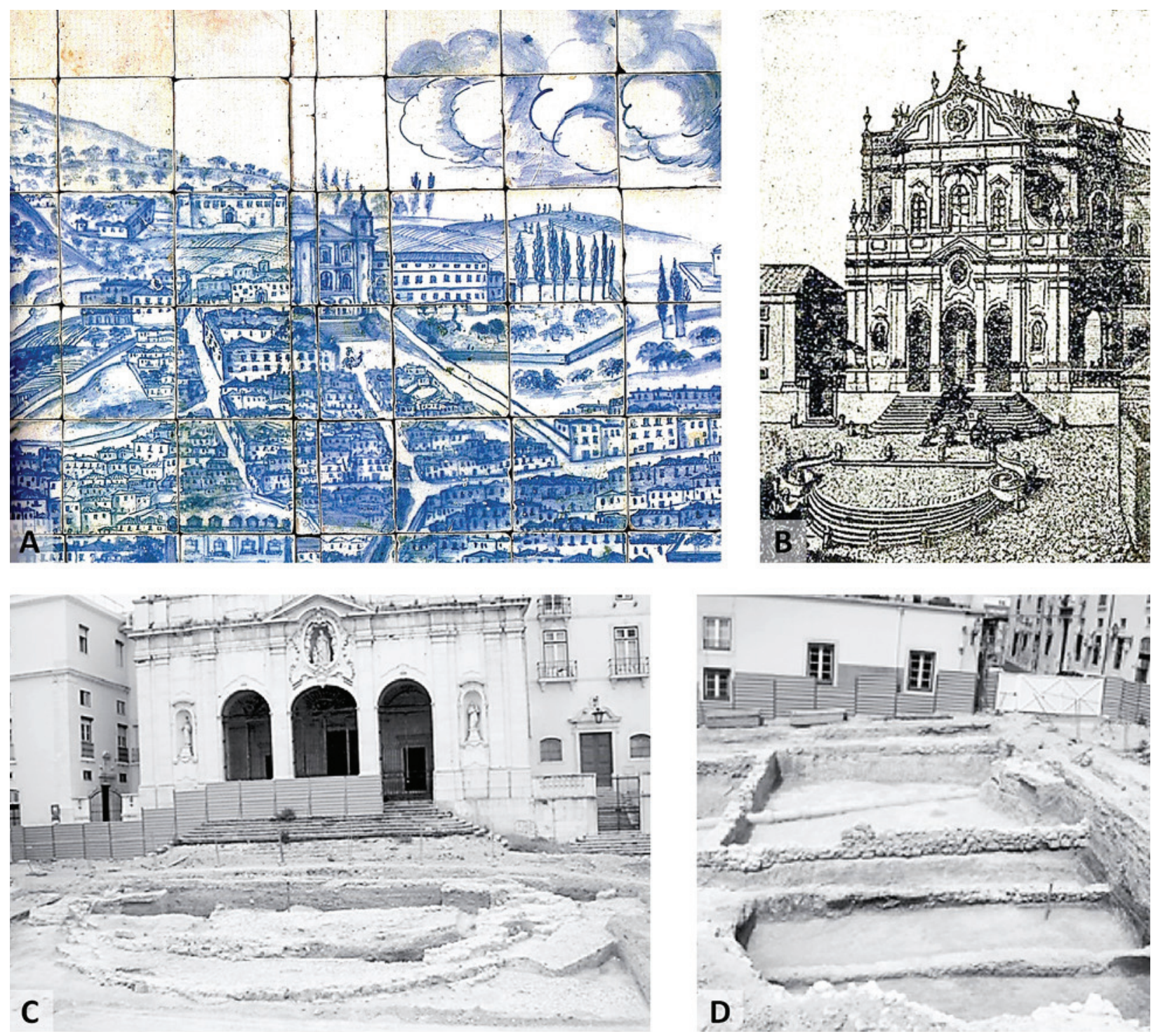

Figura 1 - Aspectos do Largo de Jesus e da intervenção arqueológicas de 2005. A - Pormenor do Grande panorama de Lisboa (Gabriel del Barco, 1750 - Museu Nacional do Azulejo. Foto: Carlos Boavida); B - Vista da fachada da Igreja de Jesus (autor desconhecido, séc. XIX - seg. Ferreira de Andrade, 1945); C/D - Vistas gerais dos trabalhos arqueológicos ocorridos no Largo de Jesus (seg. Santos, 2007). 
$1 / 1$

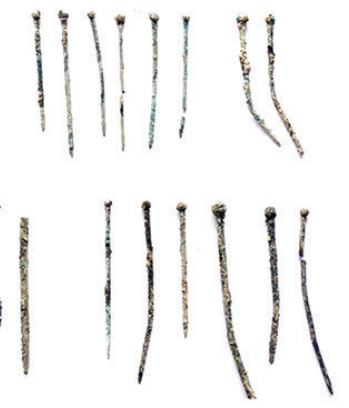

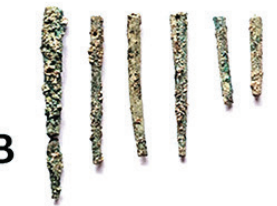

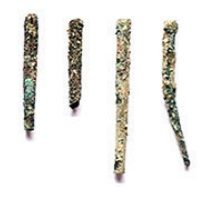

D 6
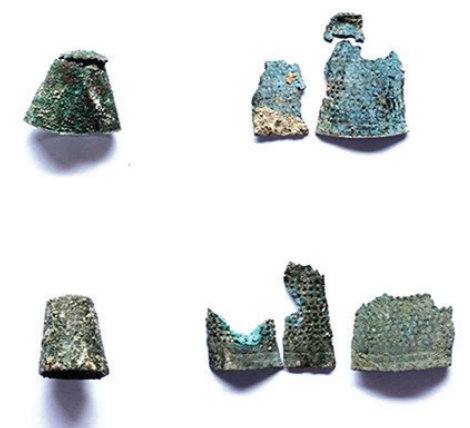

C

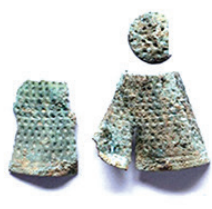

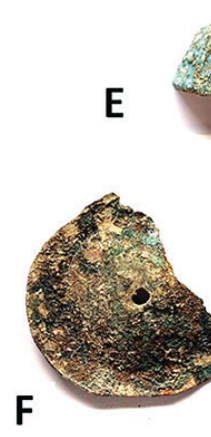
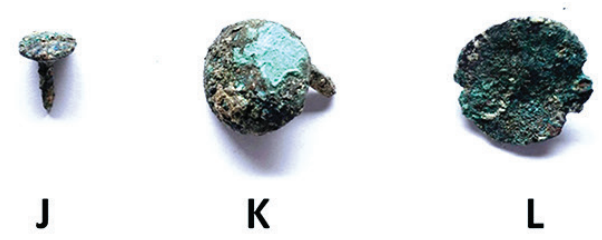

J

L
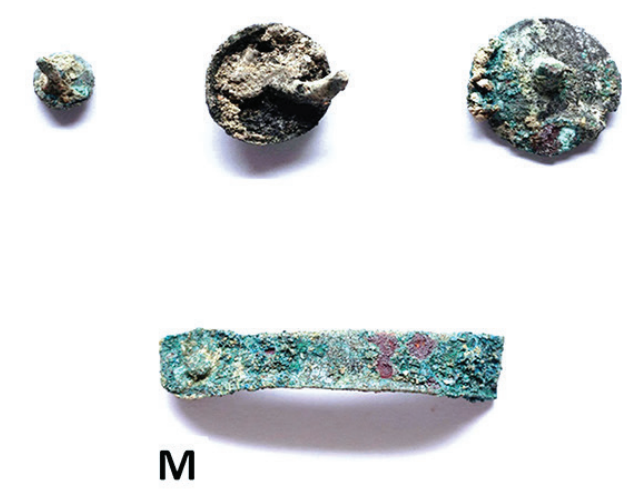

G
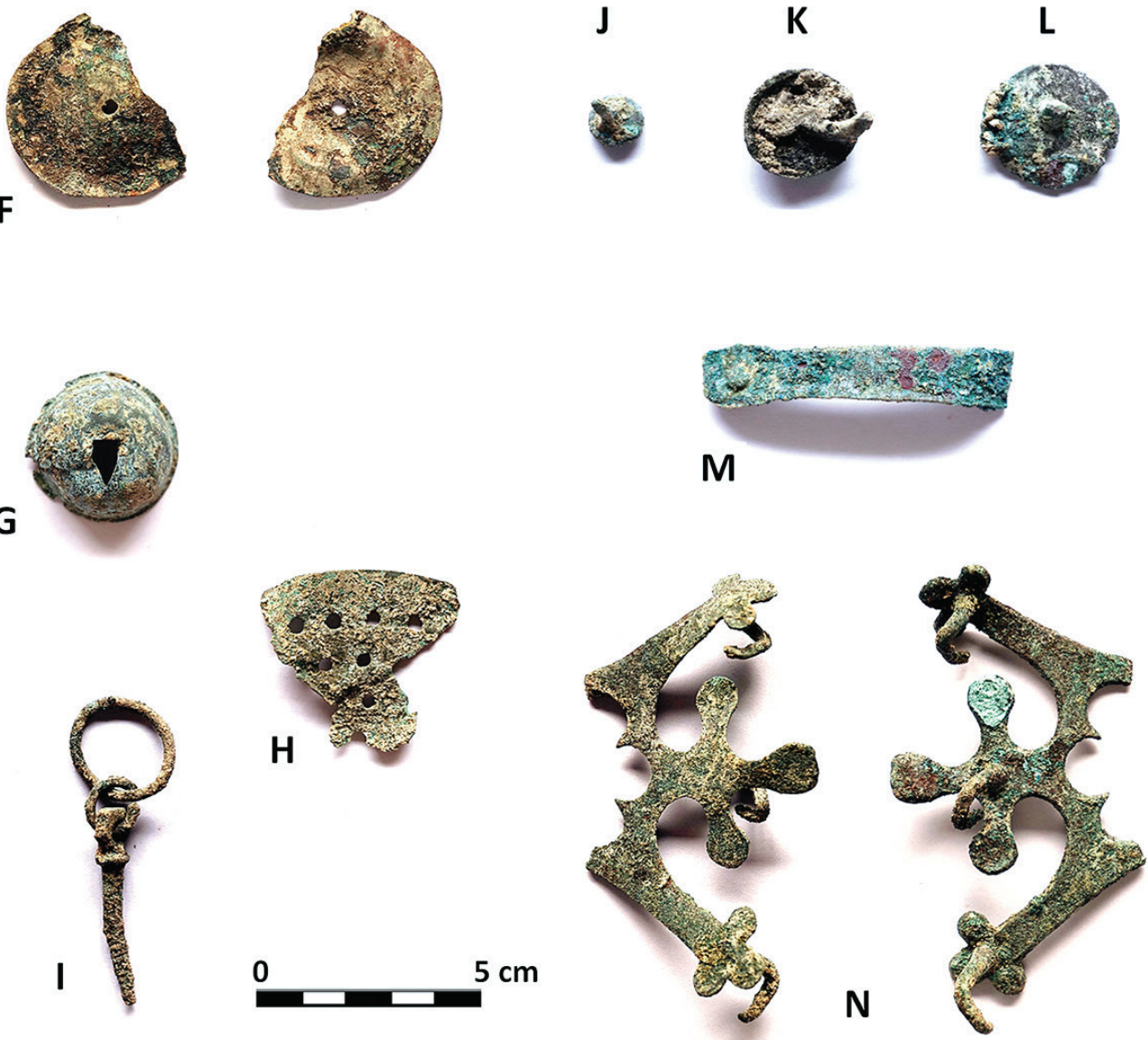

Figura 2 - Objectos metálicos recuperados no Largo de Jesus. A - Alfinetes; B - Agulhetas; C- Dedais; D - Colchete; EGuizo (fragmento); F-Címbalo; G - Peça de cabo de faca; H - Escumadeira (fragmento); I - Espigão e argolas de tampa de garrafa; J/K/L - Pregos de cadeiras; M - Puxador; N - Dobradiça (fragmento). Fotos: Carlos Boavida. 


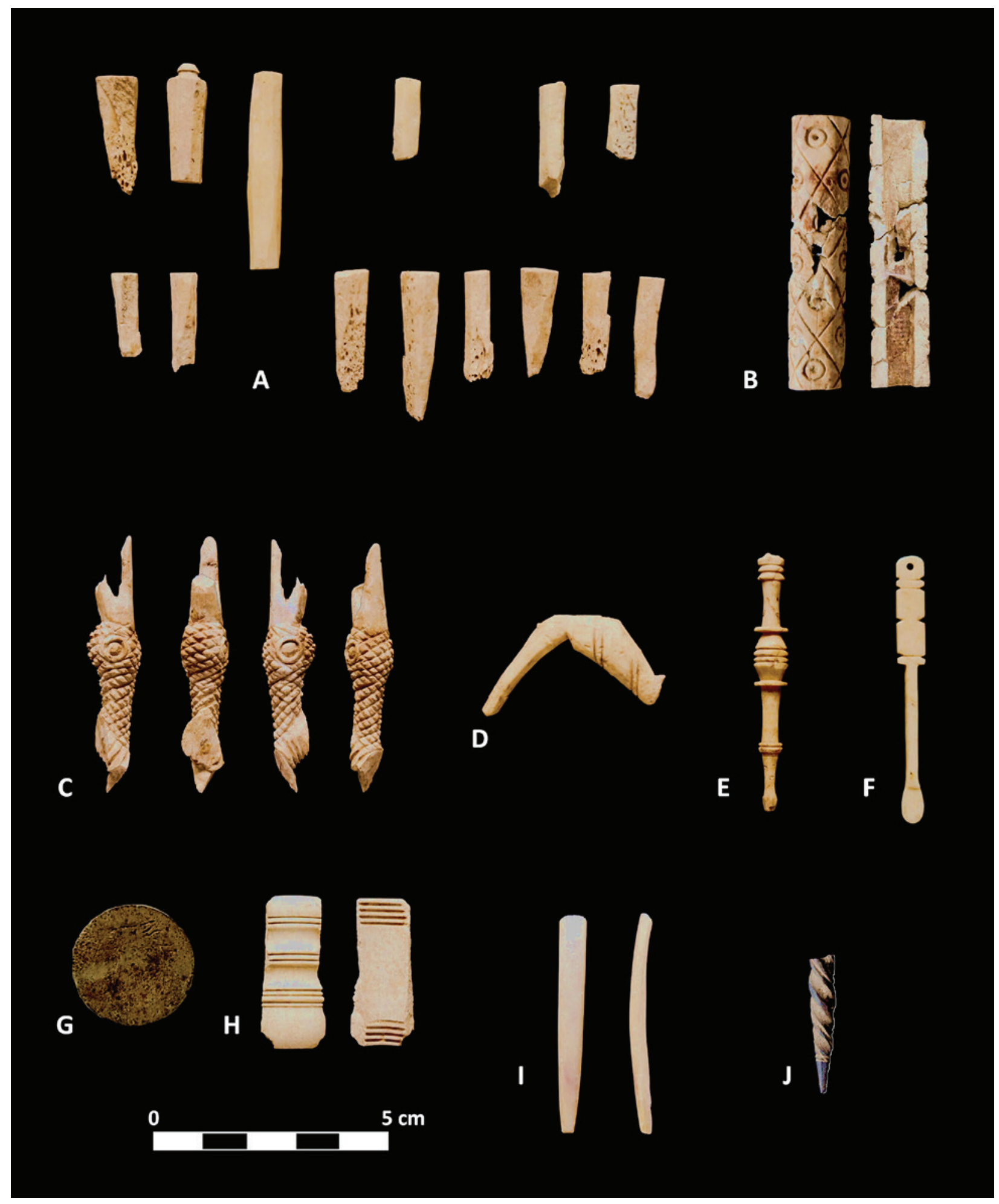

Figura 3 - Objectos em osso, marfim, madrepérola e azeviche recuperados no Largo de Jesus. A - Elementos em osso e marfim (?); B - Empunhadura de talher em osso; C - Fragmento de talher em marfim; D - Elemento decorativo em marfim; E - Pequeno bordão de peregrino em marfim; F-Colher de rapé em marfim; G-Marca de jogo em marfim; $\mathrm{H}$ - Fragmento de seringa de lavagens (?) em marfim; I - Fragmento de travessa de cabelo em madrepérola; J - Fragmento de pendente/amuleto (?) em azeviche. Fotos: Carlos Boavida. 

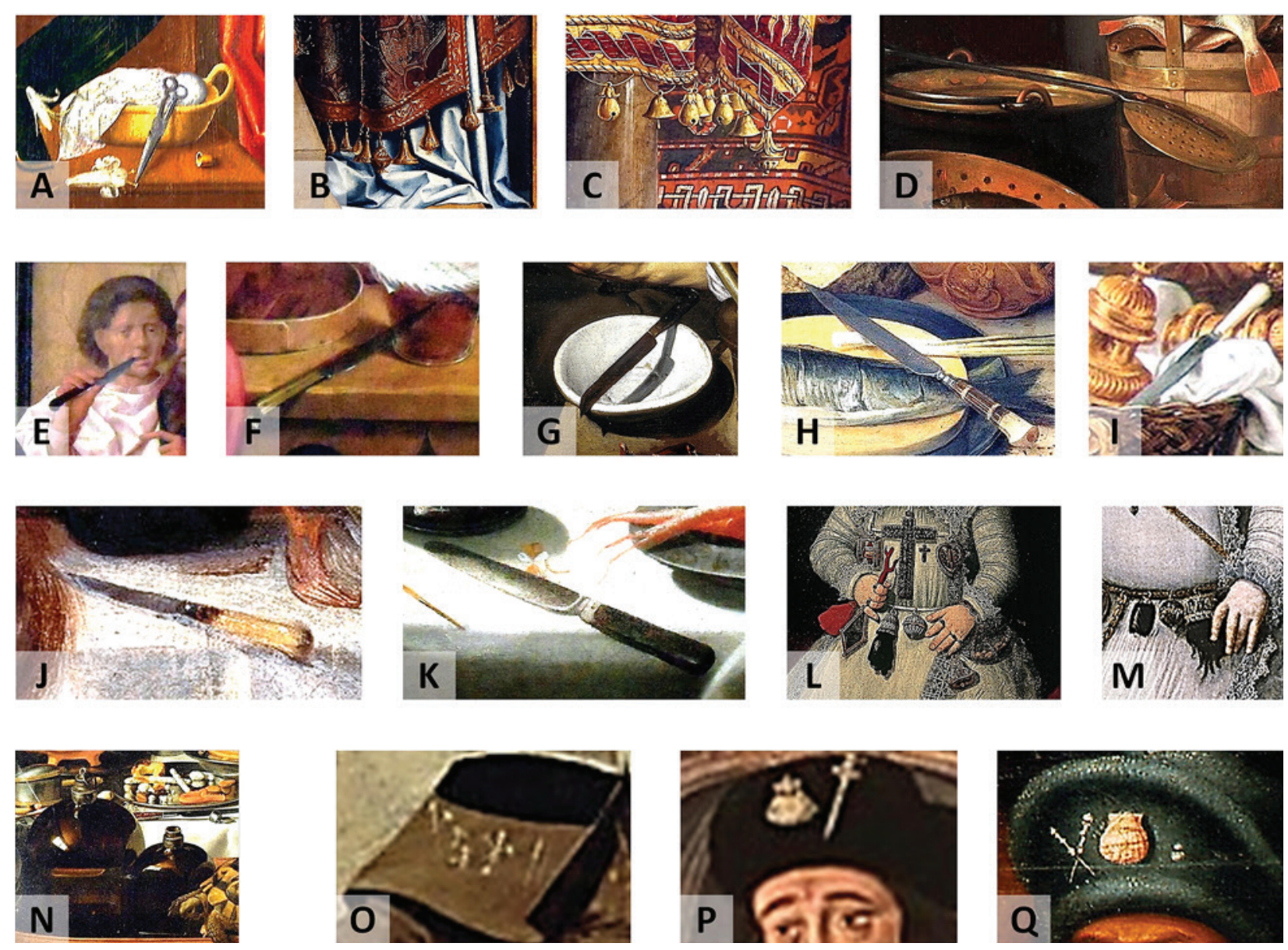

Figura 4 - Alguns pormenores iconográficos. A - Henriques e Fernandes (?), 1501/1506; B - Lopes, 1523 (?); C - Fernandes, 1538; D - Vaillant, 1650; E - Henriques, 1508/1511; F - Lopes, 1523 (?); G - Velázquez, 1618; H - Flegel, 1635; I - Pereda y Salgado, 1650/1655; J - Steen, 1661; K - Figueira, 1674; L - Pantoja de la Cruz, 16o2; M - Moran, 1610; N - Claesz, 1623; O - Autor desconhecido, séc. XVII; P- Oficina de Mestre Hilário, início do século XVI; Q-Mestres de Ferreirim, 1. ${ }^{\text {a }}$ metade do século XVI. 


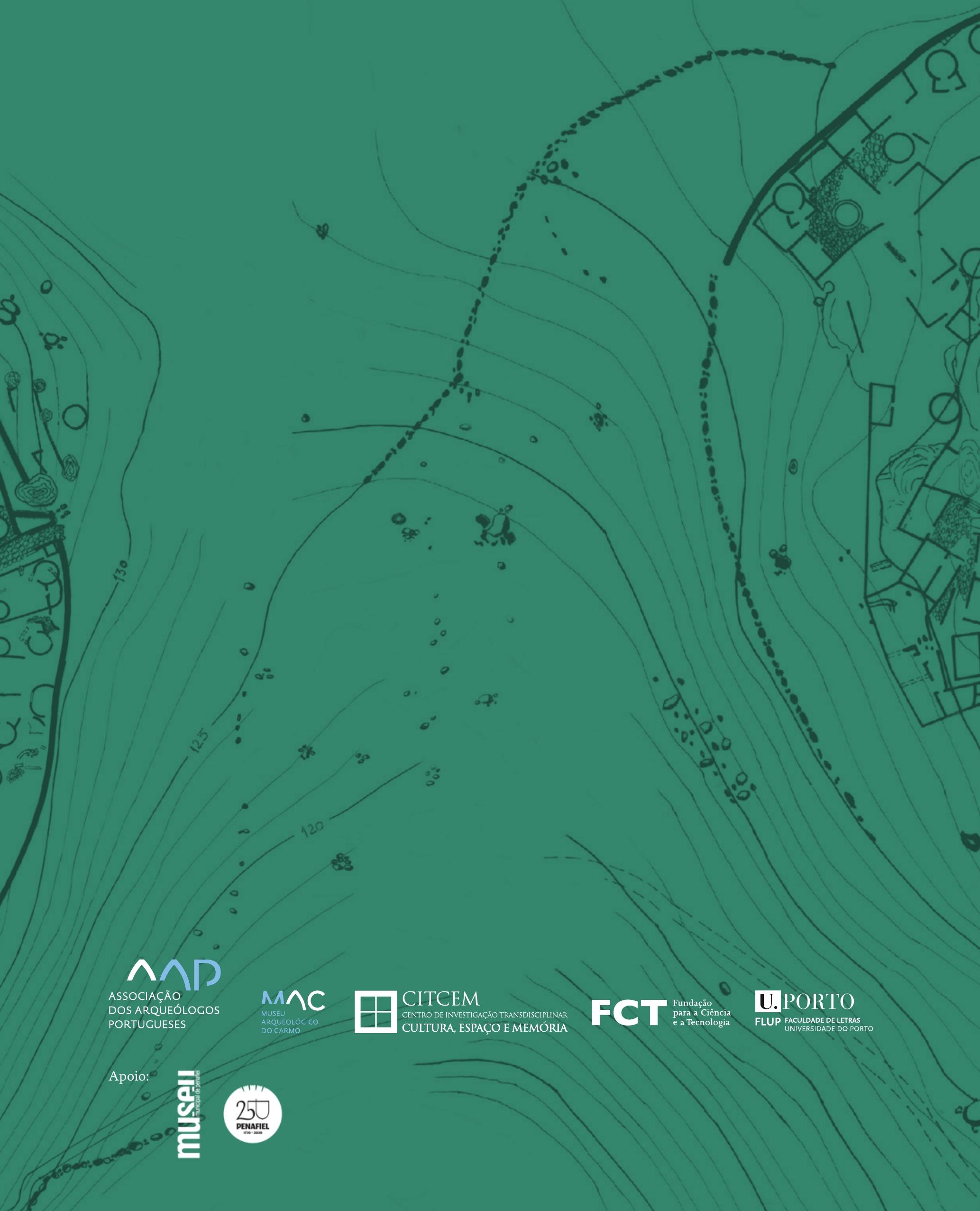

